\title{
Linfoma não Hodgkin simulando hanseníase virchowiana *
}

\section{Non-Hodgkin's Lymphoma simulating Lepromatous Leprosy ${ }^{*}$}

\author{
Vanessa Barreto Rocha ${ }^{1}$ \\ Marcelo Grossi Araújo
}

\author{
Saôny Victor de Carvalho \\ Antônio Carlos Martins Guedes ${ }^{4}$
}

\begin{abstract}
Resumo: Os autores relatam caso de linfoma não Hodgkin em paciente do sexo feminino, de 28 anos, ressaltando o diagnóstico diferencial com formas multibacilares de hanseníase. Além de achados clínicos passíveis de confusão, a histologia mostrava, de modo não usual, infiltrado inflamatório mononuclear perineural e perianexial.

Palavras-chave: diagnóstico; diagnóstico diferencial; hanseníase; linfoma não Hodgkin.
\end{abstract}

Summary: The authors report a case of a 28-year-old woman with non-Hodgkin's lymphoma, first diagnosed as multibacillary leprosy. The differential diagnosis is discussed, with emphasis on leprosy, since there were similarities in the clinical aspects. Furthermore the bistopathological findings were unusual, displaying perineural and periannexal inflammatory infiltrate composed of mononuclear cells.

Key-words: diagnosis; diagnosis, differential; leprosy; lymphoma, non-Hodgkin.

\section{INTRODUÇÃO}

Os linfomas não Hodgkin representam um grupo heterogêneo de neoplasias com diferenças na apresentação clínica, histologia e no curso clínico. Os linfomas cuja manifestação clínica inicial se dá na pele são freqüentemente de diagnóstico difícil e têm comportamento clínico enigmático.

$\mathrm{O}$ exame histopatológico deve distinguir os linfomas de várias entidades benignas que cursam com infiltrado inflamatório linfomatóide. Dessas podem ser citados linfocitoma cútis, infiltração linfocítica de Jessner, pitiríase liquenóide aguda, hiperplasia linfóide cutânea e, neste caso, de modo não usual, hanseníase. ${ }^{1,2}$ Do ponto de vista clínico, o polimorfismo das lesões cutâneas coloca várias

\section{INTRODUCTION}

Non-Hodgkin's lymphomas represent a heterogeneous group of neoplasias with differing clinical presentation, histology and clinical course. Those lymphomas with initial clinical manifestation in the skin are frequently difficult to diagnose and present an enigmatic clinical behavior.

The histopathological exam should distinguish between the lymphomas of various benign entities which course with an inflammatory lymphomatoid infiltrate. These include cutaneous lymphocytoma, Jessner's lymphocytic infiltration, acute lichenoid pthiriasis, cutaneous lymphoid hyperplasia and, as in this case though unusually, leprosy. ${ }^{1,2}$ From the clinical point of view, such polymorphism of the cutaneous lesions presents several diagnos-

Recebido em 29.11.2001. / Received in November, $29^{\text {h }}$ of 2001

Aprovado pelo Conselho Consultivo e aceito para publicação em 04.06.2002. / Approved by the Consultive Council and accepted for publication in June, $04^{\text {th }}$ of 2002.

* Trabalho realizado no Serviço de Dermatologia do Hospital das Clinicas da Universidade Federal de Minas Gerais. / Work done at Dermatology Service of "Dermatologia do Hospital das Clinicas da Universidade Federal de Minas Gerais".

${ }^{l}$ Residente em Dermatologia do Hospital das Clínicas - UFMG. / Dermatology Resident at the Hospital das Clínicas - Federal University of Minas Gerais (HC-UFMG).

${ }^{2}$ Graduando em Medicina (12o Período) da Faculdade de Medicina - UFMG. / 12th period medical student, Faculty of Medicine - UFMG.

${ }^{3}$ Professor Assistente de Dermatologia do Departamento de Clínica Médica da Faculdade de Medicina da UFMG, Mestre em Medicina, Coordenador do Ambulatório de Hanseníase do HC

- UFMG. I Assistant professor of Dermatology, Dept. of Clinical Medicine, Faculty of Medicine - UFMG, Masters in Medicine, Coordinator of the Leprosy Ambulatory HC - UFMG.

${ }^{4}$ Professor Adjunto de Dermatologia do Departamento de Clínica Médica da Faculdade de Medicina da UFMG, Doutor em Medicina, Coordenador do Serviço de Dermatologia do HC-

UFMG. / Adjunct Professor of Dermatology, Dept. of Clinical Medicine, Faculty of Medicine - UFMG, Ph.D. Medicine, Coordinator of Dermatology service, HC- UFMG. 
possibilidades diagnósticas e, quando ocorre infiltração da pele e surgem placas e nódulos, a possibilidade de hanseníase multibacilar deve ser considerada.

\section{RELATO DO CASO}

Paciente do sexo feminino, de 28 anos, servente escolar, natural de Ubaporanga e residente em Caratinga, MG, foi atendida pela primeira vez no Serviço de Dermatologia do HC-UFMG em setembro de 2000. Relatava ser hígida até fevereiro, quando iniciou com lesões hipercrômicas assintomáticas no abdômen e dorso que, após biopsiadas, foram diagnosticadas como hanseníase. Foi tratada com poliquimioterapia esquema II da OMS (PQT II) durante seis meses, evoluindo com anemia importante, atribuída à hemólise por dapsona. Apresentou, também, edema poliarticular, piora das lesões da pele e surgimento de nódulos cervicais, interpretados como quadro reacional, para o qual foi iniciada prednisona $1 \mathrm{mg} / \mathrm{kg} / \mathrm{dia}$.

Ao exame clínico apresentava-se com estado geral comprometido, placas ictiósicas e várias lesões esclerodermiformes disseminadas; a face mostrava-se infiltrada bem como, de modo marcante, os pavilhões auriculares, não se notando madarose (Figuras 1 e 2). Não apresentava neurite ou espessamento neural nem alteração de sensibilidade. Apresentava, ainda, linfadenomegalia muito importante em várias cadeias, com linfonodos endurecidos, confluentes, aderidos. O exame abdominal revelou fígado a $8 \mathrm{~cm}$ do rebordo costal direito e tamanho do baço aumentado (Boyd III).

Exames complementares: adenomegalia hilar importante na radiografia de tórax, hipoalbuminemia $(2,8 \mathrm{~g} / \mathrm{dl})$, anemia importante ( $\mathrm{Hb} 8,2 \mathrm{~g} / \mathrm{dl})$, normocítica normocrômica, leucocitose $\left(12500\right.$ células $\left./ \mathrm{mm}^{3}\right)$ com linfocitose $(77 \%$ = 9625) e presença de blastos no sangue periférico. A tic possibilities and when associated with infiltration of the skin with onset of plaques and nodules, the possibility of multibacillary leprosy should be considered.

\section{CASE REPORT}

Female patient, 28 years old, school worker, born in Ubaporanga and resident in Caratinga, Minas Gerais State, was attended for the first time at the Dermatology Service of HC-UFMG [Hospital das Clínicas, Federal University of Minas Gerais] in September, 2000. She was reportedly healthy until February, when she noticed the onset of asymptomatic hyperchromic lesions in the abdomen and back. After biopsy these were diagnosed as leprosy. She was treated with polychemotharapy (PQT) according to the WHO regimen II (PQT II) for six months, coursing with important anemia, attributed to dapsone induced hemolysis. She also presented polyarticular edema, aggravation of the skin lesions and onset of cervical nodules, this was interpreted as a reactional picture, for which $1 \mathrm{mg} / \mathrm{kg} /$ day prednisone was initiated.

At clinical exam she presented with a poor general state, ichthyosiform plaques and several sclerodermiform disseminated lesions; her face was infiltrated and also the auricular pavilions to marked degree, madarosis was not apparent (Figures 1 and 2). She did not present neuritis, neural thickening nor sensitivity alterations. Furthermore, she presented very important enlarged lymph nodes in several chains, with hardened, confluent and adhered lymph nodes. Abdominal exam revealed liver $8 \mathrm{~cm}$ from the right costal arch and enlarged spleen (Boyd III).

Complementary exams: important hilar adenomegaly in the chest $x$-ray, hypoalbuminemia $(2.8 \mathrm{~g} / \mathrm{dl})$, significant anemia ( $\mathrm{Hb} 8.2 \mathrm{~g} / \mathrm{dl}$ ) which was both normocytic and normochromic, leukocytosis (12500 cells $\left./ \mathrm{mm}^{3}\right)$ with lymphocytosis $(77 \%=9625)$ and presence of blasts in the

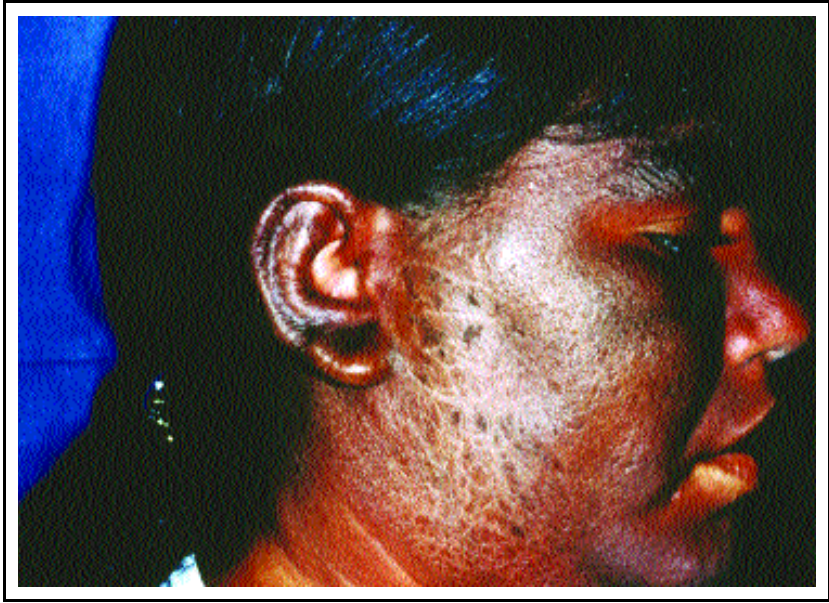

Figura 1: Placas ictiósicas e esclerodermiformes na hemiface direita, com infiltração difusa, principalmente nos pavilhões auriculares. / Figure 1: Icteroid and sclerodermatous plaques in right hemifacial region, with diffuse infiltration, specially in the auricles.

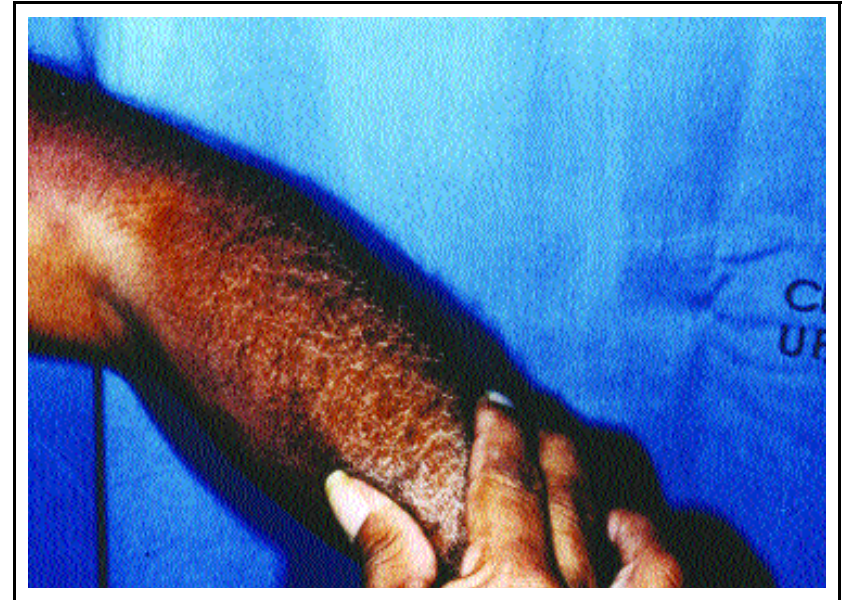

Figura 2: Placas ictiósicas e esclerodermiformes no antebraço direito. / Figure 2: Icteroid and sclerodermatous plaques in right forearm. 
pesquisa de bacilos álcool-ácidorresistentes (Baar) nas lesões, lóbulos de orelha e cotovelos foi negativa.

Foram feitas biópsia de cinco locais da pele, e a his tologia mostrou denso infiltrado constituído por células linfóides, com atipias celulares discretas, algumas figuras de mitose, em sua maioria linfócitos bem diferenciados, dis postos especialmente de maneira perivascular, por vezes confluentes, ocupando toda a derme e hipoderme (Figura 3). Firmou-se o diagnóstico de linfoma não Hodgkin. A biópsia de linfonodo mostrou subversão de sua arquitetura por massa monótona de células atípicas de nucléolos evidentes e alto índice mitótico - compatível com linfoma não Hodgkin com imuno-histoquímica $\mathrm{CD}_{3}$ fracamente positiva, sugestiva de linfoma difuso de células T (Figuras 4 e 5).

O mielograma mostrou medula hipercelular infiltrada por $84,4 \%$ de blastos, com características de leucemia linfoblástica aguda (LLA- L2).

Com o diagnóstico de linfoma não Hodgkin linfoblástico leucemizado e com avaliação clínica e laboratorial negativas para hanseníase, suspendeu-se a PQT. Foi iniciada quimioterapia, com esquema DOP (daunoblastina, vincristina e prednisona) + L-asparginase, e a paciente apresentou regressão importante das lesões (Figura 6) e melhora do estado geral, mas evoluiu com recidiva medular e foi submetida a transplante de medula óssea (irmã compatível). $\mathrm{Na}$ segunda semana depois do transplante apresentou doença enxerto versus hospedeiro envolvendo pele, fígado, trato gastrointestinal e pulmão, evoluindo para o óbito cerca de 30 dias após, apesar dos vários esquemas imunossupres sores utilizados.

\section{DISCUSSÃO}

O diagnóstico do linfoma cutâneo é, freqüentemente, um desafio em dermatologia. . $^{3,45}$

O linfoma linfoblástico é doença de alto grau de malignidade que ocorre mais freqüentemente em crianças. ${ }^{4}$ Devido à proliferação de células linfóides totipotentes, cedo ou tarde ocorre leucemização (LLA), como neste caso. Em crianças há geralmente tumor tímico associado. O prognóstico desses linfomas é ruim, e o curso, subagudo. Em peripheral blood. The test for alcohol-acid-resistant bacilli (Baar) in the lesions, ear lobes and elbows was negative.

Biopsies were performed in five sites of the skin and histology showed a dense infiltrate comprised of lymphoid cells, with discreet cellular atypia and some mitotic figures, the majority of which well-differentiated lymphocytes, arranged particularly in a perivascular manner, which were at times confluent, occupying the entire dermis and hypodermis (Figure 3). The diagnosis of non-Hodgkin's lymphoma was reached. Biopsy of the lymph node presented subversion of its architecture by a monotonous mass of atypical cells with evident nucleoli and high mitotic index - compatible with non-Hodgkin's lymphoma. $C D^{3}$ immunohistochemistry was slightly positive, suggestive of diffuse T cell lymphoma (Figures 4 and 5).

Myelogram showed a medulla with $84.4 \%$ hypercellular infiltration by blasts and with characteristics of acute lymphoblastic leukemia (ALL - L2).

Following the diagnosis of leukemid lymphoblastic non-Hodgkin's lymphoma, clinical evaluation and negative laboratory findings for leprosy, the PQT was suspended. Chemotherapy was initiated this time using the DOP regimen (daunoblastine, vincristine and prednisone) $+\mathrm{L}$ asparaginase, and the patient presented considerable regression of the lesions (Figure 6) and her general state improved, but she coursed with medullar recurrence and was submitted to bone marrow transplant (compatible sis ter). In the second week post transplant she presented graft versus host disease involving the skin, liver, gastrointestinal tract and lung. Approximately thirty days later she died despite the use of various immunosuppressive therapies.

\section{DISCUSSION}

The diagnosis of cutaneous lymphoma is frequently a challenge in dermatology. $3,4,5$

Lymphoblastic lymphoma is a disease with a high degree of malignancy that occurs most frequently in children. ${ }^{4}$ Sooner or later acute lymphocytic-leukemia (ALL) occurs due to the proliferation of totipotent lymphoid cells, as in this case. In children there is usually an associated thymic tumor. The prognostic for these lymphomas is poor
Figura 3: Cortes histológicos de pele corados pela hematoxilinaeosina, em aumento de 100x, mostrando denso infiltrado inflamatório perivascular e perianexial, constituído por células linfóides, com atipias celulares discretas, algumas figuras de mitose, sendo a maioria dos linfócitos bem diferenciados.

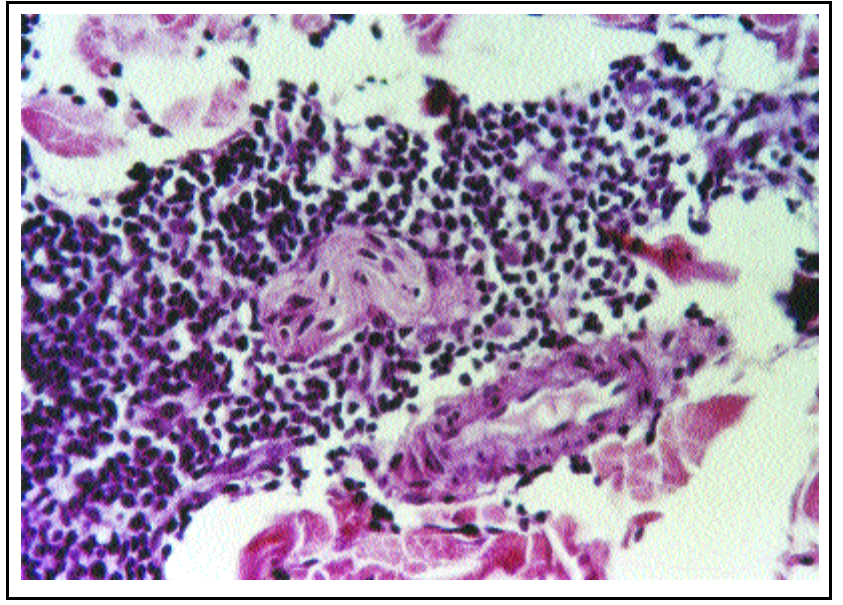

Figure 3: Histological skin sections, stained with bematoxylin and eosin (100x), showing dense, inflammatory, perivascular and periadnexal infiltrate, comprising lymphoid cells, with discrete cellular atypia and some mitotic figures, the majority of lymphocytes were well differentiated. 


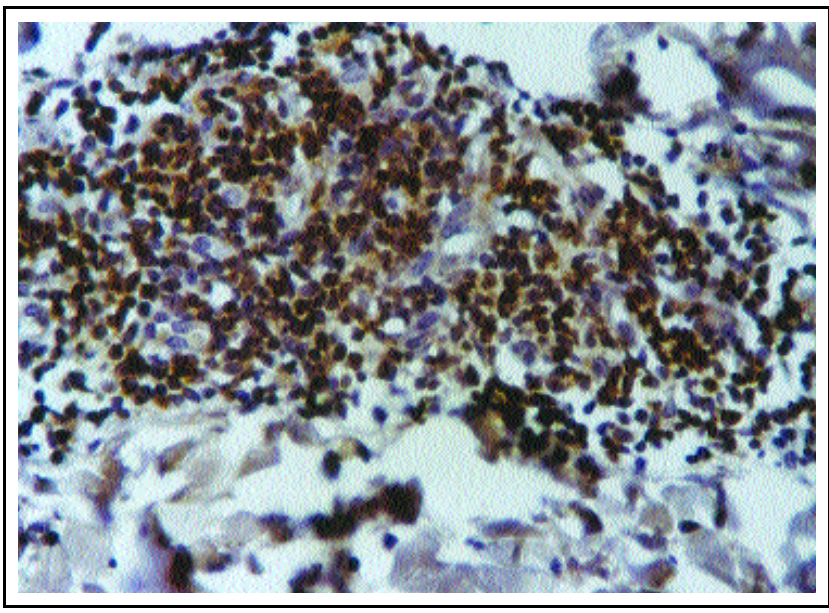

Figura 4: Imunohistoquímica de cortes histológicos de pele, em aumento de 100X, mostrando-se CD3 com marcação fracamente positiva, com infiltrado inflamatório linfóide, com presença de atipia. / Figure 4: Immunobistochemistry of histological skin sections (100X) showing CD3 with weakly positive marking, lymphoid inflammatory infiltrate and the presence of atypia.

poucos meses há metástase a distância, leucemização e curso letal.

As lesões da pele ocorrem raramente, parecem ser secundárias e se manifestam com nódulos e infiltração de extremidades, em particular no abdômen e couro cabeludo.

A histologia dos linfomas revela infiltrado inflamatório monomórfico de linfoblastos, que neste caso se mostrou com características não usuais, ${ }^{6}$ com linfócitos perivasculares, envolvendo pequenos nervos, de modo semelhante ao da hanseníase.

As formas multibacilares de hanseníase (virchowiana, dimorfa) cursam com comprometimento cutâneo importante. Caracterizam-se pela presença de manchas, placas, infiltrações nas extremidades e madarose. As alterações de sensibilidade e o espessamento de troncos nervosos são achados neurológicos importantes para o diagnóstico da hanseníase. $\mathrm{O}$ exame histopatológico da pele mostra alterações que são bem estabelecidas para as formas dimorfa e virchowiana. Já as lesões precoces e a forma indeterminada podem trazer dificuldades para o diagnóstico, mesmo para patologistas experimentados. ${ }^{7}$ Nas lesões precoces o infiltrado mononuclear envolvendo e desorganizando a estrutura ner-

Figura 6: Paciente 60 dias após primeiro ciclo de quimioterapia, com regressão importante das lesões cutâneas.

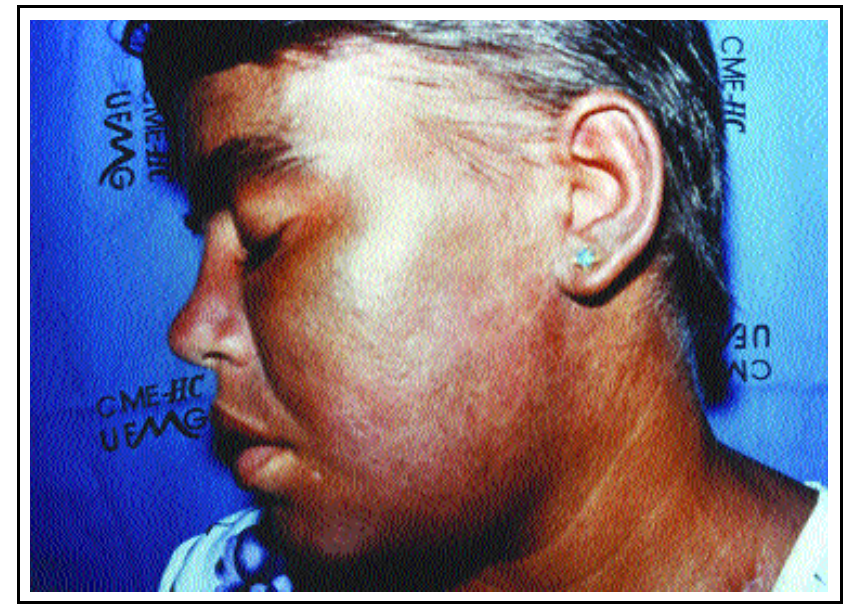

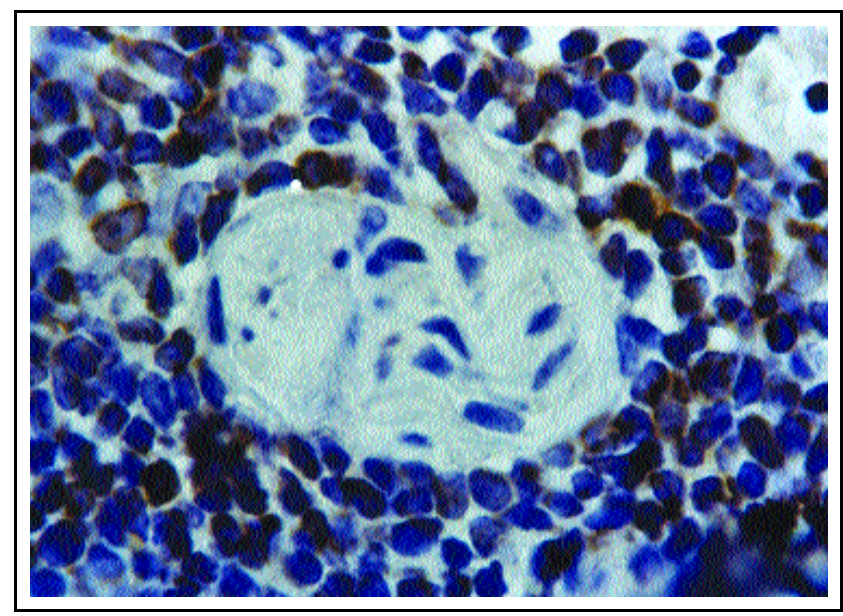

Figura 5: Detalhe da imunohistoquímica, mostrando infiltrado perineural, sem agressão ao nervo.

Figure 5: Immunobistochemical detail, showing perineural infiltration, without aggression to the nerve.

and the course is subacute. Within a few months there is distant metastasis, leukemogenesis and lethal course.

Skin lesions rarely occur and appear to be secondary. They present with nodules and infiltration of the extremities, especially in the abdomen and scalp.

The histology of the lymphomas reveals a monomorphic inflammatory infiltration of lymphoblasts, which in this case presented unusual characteristics, ${ }^{6}$ with perivascular lymphocytes, involving minor nerves, in a similar manner to leprosy.

The multibacillary forms of leprosy (lepromatous and dimorphous) course with important cutaneous involvement. They are characterized by the presence of stains, plaques, infiltration in the extremities and madarosis. Sensitivity alterations and thickening of the nerve branches are important neurological findings for the diagnosis of leprosy. Histopathological exam of the skin reveals alterations that are very well-established for the dimorphous and lepromatous forms. While the precocious lesions and indeterminate form can cause difficulty in the diagnosis, even among experi enced pathologists. ${ }^{7}$ In precocious lesions the mononuclear infiltration involving and disorganizing the nerv-

Figure 6: Patient 60 days after first cycle of chemotherapy, with significant regression of the cutaneous lesions. 
vosa deve levar à suspeita de hanseníase. ${ }^{8}$

Deve ser ressaltado o fato de que a baciloscopia no caso relatado foi negativa desde o início, assim como a pesquisa de bacilos nos fragmentos de biópsia corados pelo Wade. O quadro clínico acima descrito e os exames realizados permitiram afastar o diagnóstico de hanseníase.

Sabendo-se que o Brasil é o segundo país tanto na incidência anual de hanseníase (42.055 casos registrados em 1999 - 2,59/10.000) como na prevalência (78.068 casos registrados em 1999 - 4,3/10.000hab), ${ }^{9}$ e, sabendo-se da necessidade de diagnóstico e tratamento precoces dessa doença e da raridade das manifestações cutâneas primárias nos linfomas, salienta-se a dificuldade do diagnóstico diferencial que casos como o relatado podem trazer para o trabalho de campo. ${ }^{10,11}$

\section{REFERÊNCIAS / REFERENCES}

1. Garvin, AJ. et al. An Autopsy Study of Histologic Progression in Non-Hodgkin's Lymphomas. Cancer 1983; 52: 393-398.

2. Burke, JS. et al. Cutaneous Malignant Lymphomas. Cancer; 1981: 47: 300-310.

3. Braun-Falco, O. et al. Dermatology. Berlin: Springer-Verlag, 1991: 1082-1101.

4. Linfoma não-Hodgkin. In: Wintrobe, M. N. et al Wintrobe Hematologia Clínica. 1a edição. São Paulo: Manole, 1998:

5. Nathwani, BN. et al. Malignant Lymphoma, Lymphoblastic. Cancer 1976; 38: 964-983.

6. Derringer, GA. et al Extranodal spread of anaplastic large cell (CD30+) Lymphoma presenting as a cutaneous perivascular infiltrate. J Cutan Pathol 1996; 23: 323-327.

7. Fine, P. E. M. et al. Comparability among histopathologists in the diagnosis and classification of lesions suspected of leprosy in Malawi. J Leprosy 1986; 54: 614-625.

8. Job, CK. Pathology of Leprosy. In: Hastings, R.C. \& Opromolla, D.V.A. Leprosy. $2^{\mathrm{a}}$ edição. Edinburgh: Churchill Livinsgtone, 1994: 193-224. ous structure should lead to the suspicion of leprosy. ${ }^{8}$

The fact should be emphasized that bacilloscopy in the reported case was negative since onset, as well as tests for bacilli in the biopsy specimens prepared with Wade-Fite stain. The above described clinical picture and exams enabled the diagnosis of leprosy to be discarded.

Since it is known that Brazil is the second country in terms of the annual incidence of leprosy (42,055 cases registered in 1999 - 2.59/10,000) and prevalence (78,068 cases registered in 1999 - 4.3/10,000), ${ }^{9}$ and given the need for precocious treatment and diagnosis of this disease together with the rarity of primary cutaneous manifestations in the lymphomas; the authors underscore the difficulty in the differential diagnosis that cases such as this can cause for field work. . $^{10,11}$

9. World Health Organization. Leprosy - Global situation. Weekly Epidemiological Records [on line], 2000; 75 (n. 28): 226-231. Disponível na Internet: 〈http:www.who.int/wer〉

10. Croft, R. et al. Case Report: Cutaneous Lymphoma and Borderline Leprosy simulating Lepromatous Leprosy. Lepr Rev 1996; 67: 145-147.

11. Balanchandran, C. et al. Cutaneous Lymphoma masquerading as Lepromatous Leprosy. Int Lepr 1990; 58: 115-161.

ENDEREÇO PARA CORRESPONDÊNCIA: / MAILING ADDRESS:

Marcelo Grossi Araújo

Rua Ouro Fino, 215/801 Cruzeiro

Belo Horizonte MG 30310-110

Tel/Fax: (31) 3241-3096 / 3226-3066

E-mail:mgrossi@medicina.ufmg.br 